\title{
Emerging Technology Innovation in Gaza Strip Municipalities: An Entrepreneurial Approach
}

Ashraf AlAstal ( $\sim$ ashraf.y.a@ieee.org )

Islamic University of Gaza

\section{Research}

Keywords: Municipalities, public sector, open innovation, entrepreneurship, technological start-ups, emerging technologies

Posted Date: September 23rd, 2021

DOI: https://doi.org/10.21203/rs.3.rs-853222/v1

License: (c) (i) This work is licensed under a Creative Commons Attribution 4.0 International License. Read Full License 


\section{Abstract}

To boost corporate efficiency in both the public and private sectors, innovation is fundamental. Efficient technological transfer and the role of public-private sector collaboration play a major role in the modern growth of knowledge-based economies. As a public service organization, municipalities normally coordinate with all partners to draw up strategies and use them in communities. A new vision is needed for the Gaza Strip municipalities, where all public and private stakeholders work together to co-design and co-develop new cutting-edge products and services aimed at generating shared value through entrepreneurial behaviour. However, concrete examples of smart city projects revealed that municipalities often do not have the necessary capabilities as well as innovative approaches to collaborate with start-ups and other stakeholders' ecosystems. So, this paper aims at analyzing (open) innovation in the municipal sector shedding lights on the barriers and challenges that municipalities in Gaza Strip face in smart city development. This study uses primary data gathered from various stakeholders through focus groups, semi-structured interviews and webinars to demonstrate how municipalities can work to address challenges in the smart city context, and to promote an ecosystem of entrepreneurship and innovation. Gaza Strip municipalities need to offer the necessary conditions for entrepreneurial talents who can bring their creative mindset, and technological experiences to the table, making it possible to build the best teams to solve any challenge. The research also concluded that Open Innovation Platforms can be seen as an important tool for enabling start-ups and researchers in developing emerging technologies.

\section{Introduction}

Businesses need to continuously adjust to evolving market pressures to ensure that customer loyalty is delivered in a way that creates business growth (Burnett, 2011). More businesses are looking to start-ups and entrepreneurs for ideas and solutions (Sheppard, McCarron, Gelb, Mabbott, \& Fogarty, 2015) to bring new thinking into their organizations and to challenge the status quo. Emerging companies such as start-ups prefer to carry out research and development more seriously because they attach considerable importance to the growth and development of new technologies (Potjanajaruwit \& Girdwichai, 2019).

The public sector plays a major role in modern economies, as it does in the business world. Innovation can therefore be a significant source of productivity growth, cost savings and enhanced service quality. Innovation is important to better respond to society's changing and growing needs. Public organizations exist because nations need them. Dube \& Danescu (2011) described the public sector as it consists of government and all publicly controlled or publicly funded agencies, enterprises, and other bodies that deliver public programs, goods, or services (Dube \& Danescu, 2011). Public sector organizations often operate in a linear fashion that runs counter to a swift decision-making process (Jullien \& Lemardeley, 2018). Drivers, such as the availability of expertise or funding, may serve as barriers to innovation through their absence.

While most public sector organizations are currently slow to adopt new technologies (Orton-Jones, 2018), the world is evolving, and more organizations are starting to see the importance of transferring to emerging technology even before they face any causes. Municipalities -as public sector organizations- usually coordinate with all stakeholders for setting plans and using them in cities. A new vision for the municipalities in Gaza Strip is required, whereby public decision-makers become public entrepreneurs to support the adoption of new hi-tech technologies. This can only happen through a mindset that relies on experimentation, managed risk-taking, and an agile and tailor-made approach to new challenges. This will help promote the creation of an ambitious municipal sector that can become a much-needed growth engine for the Palestinian economy.

The aim of this research was to examine the technological entrepreneurship opportunities through looking at the challenges facing municipalities in the Gaza Strip area and develop an innovation framework that can influence the municipalities' innovativeness. Therefore, this study explores the opportunity for cooperation between the creativity of the technology startups and the innovativeness of the municipality. The following section of this document shows the literature review for this study. Subsequently, the methodology is explained and the main results are shown and discussed. Finally, the conclusion of this work is presented. 


\section{Technology-Enabled Municipal Innovation}

The innovations appearing within the public sector are given special attention by researchers. A rich literature has been generated to study public sector innovation. Public sector innovation has been described as designing and introducing new processes, products, services and delivery methods, leading to substantial changes in productivity, efficiency or quality of performance. (Mulgan \& Albury, 2003). Serrat (2017) added that innovation is not an action or event; it is a concept, process, practice and capability that distinguishes effective organizations (Serrat, 2017). In short, innovation is the application of new ideas to produce better outcomes. Public service innovation efforts need to undergo several stages to achieve optimal implementation (Kusumasari, Pramusinto, Dwi Santoso, \& Audori Fathin, 2019). If innovation breaks new ground, the deployment process must be broken into manageable stages. Tackling each step of the innovation process is the most significant challenge for any public agency. These phases involve new approaches and a change in the organization's culture. But the greatest impact comes from linking all of them together into a cohesive innovation structure (Mulgan, 2014).

In both the private and public sectors, innovation can be crucial to stimulating economic growth and development by reducing costs and improving services (Karakas, 2020). Kay and Goldspink (2013; 2016) conducted a series of separate studies and identified general discrepancies between public and private organizations and emphasized that innovation is a vital strategy in addressing the challenges of an organization. The researchers concluded that public sector performance is characterized by the department head addressing two factors. The first is the degree of confusion kept by the head of the department about the state of their organization and the political climate in which it operates. The second is the level of proactivity, whether the activity of innovation is part of the planned strategy and thus proactive or in response to an external stimulus (Kay \& Goldspink, 2013; 2016).

Municipalities are public sector organizations. The municipal organization comprises an administration and departments, which organize and manage municipal tasks. Municipal organizations are responsible for providing many of the public services within their local city boundaries such as road repairs, cleaning and solid waste removal services, energy and water management, financial and tax collections, arts and culture, libraries and other municipal tasks. Shearmur and Poirier (2016) explained how a municipality might resemble a business firm. It has a municipal (corporate) identity; it has a mayor (director), a council (board), administration and departments. It also comprises citizens (clients) with whom interactions are necessary and from whom feedback is important (Shearmur \& Poirier, 2016).

Previous literature of technology innovation shows that technology infrastructure is a basic condition for the development of e-government and smart city actions (Przeybilovicz, Alexandra Cunha, \& de Souza Meirelles, 2018). Technology innovation includes the designing or improvement of new technological products, processes and services that would benefit social, environmental, and/or economic functions within a municipality (Sawatzky, Slemon, \& Grills, 2017). A more advanced technology environment would not only allow the organization, but would also contribute to business and civil society innovation (UNECE, 2017). This means that by taking into account the economic, environmental and social aspects of urbanization, technology and innovation can help achieve sustainable urban development.

Palestinian municipalities are responsible for planning public services and organizing cities. In the West Bank, there are 119 municipalities distributed through 11 governorates, meanwhile in the Gaza Strip, there are 25 municipalities distributed through five governorates (MDLF, 2019). The capacity in the municipalities varies widely across their various kinds, depending on the resources available (Rammal \& Abuoun Hamad, 2008). While the Palestinian municipalities have made tremendous progress in transferring conventional services to online services, due to budget and expertise constraints, there is still a long way to achieve seamless online services systems (MOLG, 2018).

Generally speaking, the Palestinian municipalities are familiar with using maps to figure out where to go, or how to plan city services through technology such as Geographic Information Systems (GIS). Access to GIS allows municipality workers to capture, store, manipulate, analyze, manage and present spatial or geographic data (Waghmare, Patil, \& Khandekar, 2015). Whereas in the past municipal staff used to review large numbers of paper maps and separate computer files containing 
various data sets, GIS technology now enables them to submit and combine vast numbers of data sets and overlay them from one street to the municipality on maps of any scale. As municipalities increasingly rely on computer-based systems and data management, they need to work alongside with technology providers to advance innovation and stay ahead of the technology curve.

Jaffal (2018) conducted a research to highlight the challenges to digitalizing municipal services in Palestine; first, he pointed out that existing legislation regulating the local government and the ICT sector is obsolete and should be established by the local government sector under the newly adopted strategic plan (Jaffal, 2018 and Morar, 2018). Second, the dedication of the local government is a crucial factor, as the involvement of mayors and city council members in the role of the Community Service Centers (CMS) is currently restricting their role. The mayor and the city council members, therefore, have to stick to the CMS Plan, which is intended to provide services to residents without administrative intervention. Third, in terms of staff capacity, problems could occur in municipalities because their workers may not have the resources to run an e-municipality or a CMS (Jaffal, 2018 and Morar, 2018). Moreover, the staff members may be concerned about losing jobs within the municipality because digitalization also requires process changes (Jaffal, 2018).

The Municipal Development and Lending Fund (MDLF), which introduced a range of capacity-building projects to strengthen the internal management of municipalities in the West Bank and Gaza Strip, suggested the implementation of technology in municipal work (MDLF, 2009). This process was introduced through two stages; the first was to develop technical skills in the areas of finance, service and maintenance, registration of fixed assets and information management. The second stage was to incorporate the latest software technologies to automate work through information systems (Jaffal, 2018). Considering the past of local government in Palestine, this was a crucial step towards a sustainable e-municipality climate.

In conclusion, emerging technology and innovation concerns make it clear that cutting costs and enhancing services can be crucial to promoting economic growth and prosperity. However, their effects depend on how they are used, and fulfilling their potential requires thoughtful decisions regarding the implementation of both the technologies and innovativeness of municipalities. Public sector organizations (such as municipalities) and private sector organizations (such as technological start-ups) both want to implement digital solutions to solve problems in cities, but currently seem to do so with neither clear aims with their work nor proper follow-up procedures, with the risk of the implementations ending up having low, or even negative effects. Hence, there is a need for research that can support the implementation of emerging technologies and decision-making in this area, and this research aims to contribute to filling that need through looking at the challenges of municipalities in Gaza Strip area and develop innovation framework that can influence the municipalities innovativeness.

\section{Entrepreneurship and Municipal Collaboration}

While there is increasing recognition of the need for much innovation in public organizations, it is also recognized that more concerted efforts to foster innovation are required to address the economic challenges facing public organizations. A range of studies mentioned significant barriers to innovation that need to be overcome in the public sector. Cankar \& Petkovšek (2013) identified the absence of resources as the main barrier to innovation. This applies not only to the lack of financial resources, but also to the lack of expertise and staff (Cankar \& Petkovšek, 2013). Jayasena, Mallawaarachchi, \& Waidyasekara (2019) identified six strategies to overcome technology innovation challenges in the public sector in addition to the barriers. The researchers found that effective political strategy, the development of relevant policy, human capacity building, stakeholder management, effective communication and private-public partnership are essential (Jayasena et al., 2019). Importantly, the barriers must be recognised before making decisions concerning technology development (Mazurkiewicz, 2018).

Traditionally, when implementing the latest technology and investment in innovation, the public sector is lagging behind the private sector. Public workers are inherently disappointed with their digital office technologies (Orton-Jones, 2018). A survey of 400 senior officials published by Eggers \& Bellman (2015) observes that the public sector lacks the expertise and funding to provide digital public services effectively (Eggers \& Bellman, 2015). To improve this case, the public sector organizations 
should focus on services it wants to deliver rather than developing products itself and improving how it works with technology firms, large or small. The public sector must collaborate with private businesses to avoid missing new technology. The Institute of Directors (IOD) conducted two surveys in 2017 with 1887 respondents; the results show that $51 \%$ of the respondents say a new model is needed for engagement with SMEs and technology partners (IoD, 2018).

In Palestine, The private sector has been striving for economic survival for a long time, especially during COVID19 crisis. This sector, which is composed largely of small and medium-sized enterprises, has not received adequate support from the Palestinian Government. Shahwan \& Soudah (2005) conducted a study to investigate the kind of relationship existing between the public and private sectors as perceived by a representative sample of the private sector using a structured survey that was distributed to 150 small and medium-sized enterprises in the West Bank in 2004. The results indicate a low level of cooperation between the two sectors, which is often based on mistrust or negligence (Shahwan \& Soudah, 2005). Hence, there is a need to improve the concept of public-private partnership in Palestine (MDLF, 2009). This will help create confidence and trust between the various parties and enable the private sector to launch creative and profitable business ideas that will provide the necessary solutions to municipal challenges.

Innovation in Palestine could be classified as strong due to several factors such as the high percentage of youth in the population, abundance of highly educated and skilled Palestinians and the increasing national interest in innovation and entrepreneurship (PITA, 2018). This research examines the technological entrepreneurship opportunities through cooperation between the creativity of the technology start-up and the innovativeness of municipalities in the Gaza Strip area. The aim is to develop an innovation framework that can influence the municipalities' innovativeness.

\section{Methodology}

The adoption of emerging technology applications in the Palestinian municipal sector is still in its infancy. Therefore, the development and diffusion of emerging technology innovation can be best interpreted by analyzing relevant stakeholders' conceptions. The research reported in this study is exploratory and uses qualitative data. A qualitative exploratory approach allows researching dynamic, nuanced and multifaceted processes and exploring emerging themes (Cassell \& Symon, 1994). Researchers of new technologies usually have an exploratory and applied emphasis (Barnes, Buckland \& Brancheau, 1992).

In this research, qualitative data were collected in three stages. The process can be seen visually in figure (1). During the first stage, the researcher defined the initial research area and outlined the research design processes and milestones. The cornerstone of this research was the desk review because it helps to formulate a more precise problem and determine the type of information required to identify the structure of the data that needs to be collected. Such as documents and papers generated by previous researchers. The desk review includes topics related to Technology-Enabled Municipal Innovation and Entrepreneurship and Municipal Collaboration. The researcher also conducted a focus group comprised of six Information Technology professionals and experts to prioritize high-tech emerging technologies that may support the decision to launch technological start-ups. This focus group was useful for exploring and pre-testing general ideas, as well as for defining relevant emerging technology areas and themes, which is suitable for the context of Palestine.

At the second stage, another focus group conducted and aimed to examine the technological entrepreneurship opportunities through looking at the challenges of (22) municipalities in Gaza Strip. Therefore, the attendees were mainly from Information Technology departments in the municipalities as well as representatives from the United Nations Development Program (UNDP). A data collection tool was designed to explore how specific trends and technologies can impact the challenges at hand. As to provide rich insights, semi-structured interviews were conducted with key information technology specialists from the municipal sector for exploring, identifying and understanding viewpoints, attitudes, and influences. The semi-structured interviews allowed the researcher to explore the issues and topics posed in focus groups with regard to drivers, challenges and benefits of the implementation of new technological developments. 
And in the third stage, two webinars were conducted with the cooperation of Business and Technology Incubator (BTI). The webinars produce rich cumulative and elaborative data by putting responses from individual participants into context. The dialogue among the webinar participants was free-flowing and versatile, which increased the possibility of new topics arising.

The first webinar focused on the development of an innovative digital economy in the light of COVID19 pandemic. Four Information Technology experts from academic, public and private sectors discussed the challenges for digital transformation in Palestine and highlighted possible cooperation opportunities between public and private sectors as to build the sustainable digital economy and mitigate the impact of COVID19. The main objective of the second webinar was to highlight the main challenges that face Gaza Municipality -as a case study- and discussed current public-private partnership (PPP) practices and models at the Palestinian local level (municipalities) with a view to providing a descriptive context and real knowledge to be used for further creation of the PPP concept and structure. The webinar explores the strengths and drawbacks of PPP practices at the local level and offers some suggestions for potential action. The participants were from Municipality of Gaza, academic, private and public organizations. All data collected during the study were gathered in a digital archive containing the transcripts, field notes and documents.

\section{Results And Discussion}

\section{Emerging Technology Themes Suitable for the Context of Palestine}

The narrative literature review identified common emerging technology trends globally appeared on the list of top emerging technologies repeatedly during the past years, but every year a few technologies move off the list, and new ones take their place (Deloitte-a, 2020, CompTIA, 2020 and Cearley, 2020). This opened the debate whether these technologies are still qualified as "emerging" or not. These technologies are still very important and have a tremendous application, which means moving increasingly towards a mainstream application (Basole, 2018).

CompTIA (2020) created a wealth of content that monitors current technology trends and helps shape technology's potential and implementation in the near future. According to the CompTIA Emerging Technology Community the top emerging technologies are loT (Internet of Things), Big Data, Biometrics, Blockchain, Al (Artificial Intelligence), AR (Augmented Reality)/VR (Virtual Reality), Robotics and Drones (CompTIA, 2020). Figure (2) shows that the fastest-growing emerging technology adoption has been loT and Big Data followed by Biometrics. Drones and Robotics technologies were found to be in its early stages and need more exploration to become mainstream technologies. In general, the distribution of the emerging technologies by adoption mirrors the level of maturity of the organizations globally towards the implementation of these technologies.

As for the key emerging technology trends in the Middle East region, the ICT market will witness steady growth running through to 2024, Frost \& Sullivan (2020) reported that this growth will be driven primarily by government actions on digital transformation and business adoption of disruptive technologies, such as loT (Internet of Things) and Al (Artificial Intelligence). The study also highlights Edge Computing, Industry 4.0, VR (Virtual Reality), Blockchain \& DLT (Distributed Ledger Technology), Robotics, 3D Printing, 5G Networks and AR (Augmented Reality). Deloitte-b (2020) added Big Data and FinTech (Financial Technologies) (Frost \& Sullivan, 2020 and Deloitte-b, 2020). FinTech start-ups retained its top spot in 2019 and accounted for $13 \%$ of all deals followed by eCommerce start-ups with a percentage of $11 \%$ while IT Solutions sectors are promising to be developed very fast (Magnitt, 2019).

It's clear that emerging technologies have become an important factor in starting, growing and expanding businesses across all industries. The biggest question we have today is not whether or not businesses, public organisations and municipalities need to transform the way they do business, but rather, what technologies are most likely to have the biggest impact on these respective stakeholders in Palestine.

AlAstal (2018) investigates the investment landscape in Palestine start-ups to highlight the emerging technologies and promising sectors. The results indicate that starting from the year 2014 investors shows an increasing interest to invest in

Page 6/21 
new sectors such as Online Services, eCommerce, Security, Learning \& Education, Food, Media and FinTech; see figure (4). The interest in eCommerce, SaaS (Software as a Service), Al (Artificial Intelligence), Entertainment \& Games, Food and Healthcare seems to be common across the years 2014-2017. FinTech and Media fields got a minor interest in the years 2014 and 2017 respectively although the regional interest in these sectors is high. The Entertainment \& Games, SaaS and eCommerce got the highest interest with comparison to the other fields during the last three years (AlAstal, 2018).

The lack of a collective understanding for the emerging technologies in the Palestinian context may impact on the uptake of learning about appropriate technologies in academic, private and public areas. Discussions on the importance of emerging technologies and their transforming effect are not new in Palestine. However, it is important to make an assessment for the case of Palestine in order to better understand the new emerging technologies for the context of the Gaza Strip and make the appropriate modification adjustments. The approach used in this qualitative study was the focus group by which a group of IT experts examined the key problem and selected a set of best practices. The results revealed four emerging technologies and two important sectors. The participants agreed that it is important to focus on Al, Big Data, loT and Blockchain emerging technologies but it is important to identify suitable challenges that can be addressed by these technologies. Adding to it eCommerce and FinTech sectors this will help to overcome many difficulties related to financial inclusion and how to support eCommerce to flourish in Palestine.

\section{Emerging Technology Opportunities In The Municipal Sector}

Municipalities' are the public sector service delivery engines in Palestine. Citizens expect from municipalities to find ways to improve its public services and municipalities need to gear up to do so. This research examined how municipalities can use emerging technologies to improve public services through looking at the challenges of municipalities in Gaza Strip.

Municipalities' representatives from Information Technology departments were being asked to list the main challenges facing the municipal work and can be solved through emerging technologies. The results revealed thirty challenges grouped into ten fields of interest as shown in figure (5).

Financial Management challenges got the highest interest with 8 challenges followed by 6 challenges for Planning \& Management field. Streets \& roads, energy, water and transportation fields got an equal interest of 3 challenges each leaving the remaining 4 challenges distributed between Infrastructure, Agriculture, Sanitation and Risk Management fields.

Although the high interest in the financial management field by municipalities, FinTech start-ups got the lowest investment opportunities as explained previously in figure (4). The interest in the planning \& management field reflects the needs in this area for planning tools, which may rely heavily on the availability of healthy and clean data. The remaining fields need to be investigated as to define properly integrated solutions as they may depend on one or more emerging technologies. Further analysis regarding this issue shown in figure (6). Among the six emerging technologies that were highlighted previously, the highest demand for building integrated technology solutions was for Big Data management solutions followed by Artificial Intelligence, Internet of Things, FinTech and Blockchain respectively. Table (1) shed more light on the initial evaluation for the integrated solutions required to overcome the challenges of the municipal sector. The municipalities' representatives did not show any interest in the eCommerce solutions although it can lower the cost of transaction for citizens by enabling them to interact with public services from their homes without having to queue at government and municipal offices.

According to Lindskog \& Wennberg (2002), public sector eCommerce has played a major role in shaping national, regional and international eCommerce standards worldwide. The researchers clarified that the establishment of an information society entails not only the simplification of information and transaction flows between governmental agencies (G2G) and the establishment of the appropriate infrastructure to provide online public services for people; Government to Citizen (G2C), but it also includes the establishment of an online service system for businesses (G2B) (Lindskog \& Wennberg, 2002).

Table (1) Municipalities challenges and the initial evaluation for emerging technologies 


\begin{tabular}{|c|c|c|c|c|c|c|c|}
\hline \multirow[t]{2}{*}{ Challenge } & \multirow[t]{2}{*}{ Field of Interest } & \multicolumn{6}{|c|}{ Initial Evaluation for Emerging Technologies } \\
\hline & & Al & $\begin{array}{l}\text { Big } \\
\text { Data }\end{array}$ & loT & Blockchain & FinTech & eCommerce \\
\hline $\begin{array}{l}\text { High operational cost for machinery } \\
\text { and cars }\end{array}$ & $\begin{array}{l}\text { Financial } \\
\text { Management }\end{array}$ & & & & & $\bullet$ & \\
\hline $\begin{array}{l}\text { Unified payment methods for public } \\
\text { services }\end{array}$ & $\begin{array}{l}\text { Financial } \\
\text { Management }\end{array}$ & & & & & $\bullet$ & \\
\hline Debt management & $\begin{array}{l}\text { Financial } \\
\text { Management }\end{array}$ & & & & & ○ & \\
\hline Financial accounting management & $\begin{array}{l}\text { Financial } \\
\text { Management }\end{array}$ & & & & & $\bullet$ & \\
\hline Contracts management & $\begin{array}{l}\text { Financial } \\
\text { Management }\end{array}$ & & & & 0 & & \\
\hline Advanced solutions for billing systems & $\begin{array}{l}\text { Financial } \\
\text { Management }\end{array}$ & & & & & $\bullet$ & \\
\hline $\begin{array}{l}\text { Forecasting for currency exchange rates } \\
\text { and raw material prices }\end{array}$ & $\begin{array}{l}\text { Financial } \\
\text { Management }\end{array}$ & & $\bullet$ & & & & \\
\hline Tenders management & $\begin{array}{l}\text { Financial } \\
\text { Management }\end{array}$ & & & & $\bullet$ & $\bullet$ & \\
\hline $\begin{array}{l}\text { Infrastructure management and } \\
\text { planning for future projects }\end{array}$ & $\begin{array}{l}\text { Infrastructure } \\
\text { Management }\end{array}$ & - & - & & & & \\
\hline $\begin{array}{l}\text { The need for an integrated solution to } \\
\text { collect and manage data for all } \\
\text { administration, financial and } \\
\text { geographical information systems }\end{array}$ & $\begin{array}{l}\text { Planning \& } \\
\text { Information } \\
\text { Management }\end{array}$ & & $\bullet$ & & & $\bullet$ & \\
\hline $\begin{array}{l}\text { Citizens data management to support } \\
\text { decision making and planning for new } \\
\text { services }\end{array}$ & $\begin{array}{l}\text { Planning \& } \\
\text { Information } \\
\text { Management }\end{array}$ & & $\bullet$ & & & & \\
\hline $\begin{array}{l}\text { Attendance systems allow office and } \\
\text { field employees to clock in and out } \\
\text { electronically }\end{array}$ & $\begin{array}{l}\text { Planning \& } \\
\text { Information } \\
\text { Management }\end{array}$ & & & 0 & & & \\
\hline Ownership and assets management & $\begin{array}{l}\text { Planning \& } \\
\text { Information } \\
\text { Management }\end{array}$ & & & $\bullet$ & $\bullet$ & & \\
\hline $\begin{array}{l}\text { An integrated solution for human } \\
\text { resources management }\end{array}$ & $\begin{array}{l}\text { Planning \& } \\
\text { Information } \\
\text { Management }\end{array}$ & & ○ & & & & \\
\hline $\begin{array}{l}\text { Data management tools to support the } \\
\text { decision of future infrastructure } \\
\text { services and city engineering }\end{array}$ & $\begin{array}{l}\text { Planning \& } \\
\text { Information } \\
\text { Management }\end{array}$ & & ○ & & & & \\
\hline $\begin{array}{l}\text { Improving communication channels } \\
\text { with farmers to follow up planting and } \\
\text { harvesting activities }\end{array}$ & Agriculture & & & $\bullet$ & & & \\
\hline $\begin{array}{l}\text { Streets and roads maintenance based } \\
\text { on the usage of cars }\end{array}$ & Streets \& Roads & - & ○ & & & & \\
\hline $\begin{array}{l}\text { Follow up streets and roads that need } \\
\text { maintenance }\end{array}$ & Streets \& Roads & ○ & ○ & ○ & & & \\
\hline $\begin{array}{l}\text { Solving the problems of traffic } \\
\text { congestions }\end{array}$ & Streets \& Roads & - & & & & & \\
\hline
\end{tabular}


Sanitation management to ensure optimal processing

Minimizing energy consumption for public utilities and controlling operational cost

controlling and managing the lighting networks in the streets to minimize energy consumption

Prioritize maintenance activities in the lighting networks

The difficulties to control water wells and tanks to ensure equal distribution for citizens

Difficulties to control water valves due Water to data collection problems

Monitoring system for water network to Water avoid thefts and leakages

A live tracking system that will allow tracking with precision cars and field employees

Identification of machinery that needs support and maintenance

Follow up waste collection cars to define to the shortest path for data collection as to minimize costs

Building early warning systems for natural disasters

Risk

Management

Source: (Articulated by the researcher, 2020)

\section{Entrepreneurship and Municipal Innovation}

The previous sections discussed emerging technology themes suitable for the context of Palestine through analyzing emerging technology trends globally and looking at the challenges of municipalities' in the Gaza Strip area. This part of the research will discuss the technological entrepreneurship opportunities to develop an innovation framework that can influence the municipalities' innovativeness. Public sector organizations (such as municipalities) and private sector organizations (such as technological start-ups) both want to implement digital solutions to solve problems in cities, but currently seem to do so with neither clear aims with their work nor proper follow-up procedures.

The need for organizations to develop their creative ability has been an important motivator for exploring new ways to discover and leverage ideas that reach beyond organizational boundaries, one of these being the business model called Open Innovation (Chesbrough, 2003). The open innovation practices were said to have an impact on innovation and entrepreneurship due to the complementarities and uniqueness of the tools and expertise each organization offers (Ferraris, Santoro \& Claudia Pellicelli, 2020). Chesbrough (2003) researched companies that have modified their innovation model and concluded that R\&D is evolving into a new paradigm that requires a new form of the rationale for developing and profiting from innovation (Chesbrough, 2003).

The R\&D process relies on internal laboratories and resources in the conventional closed innovation model, while new ideas and innovations are researched and presented through internal resources, see figure (7a). Depending on the availability of resources, the capacities within municipalities vary significantly across their different forms (Rammal \& Abuoun Hamad, 2008). Even though the Palestinian municipalities have made considerable progress in moving traditional services to online 
services, there is still a long way to reach seamless online services' systems due to budget and skills limitations (MOLG, 2018). Open innovation has emerged as a model for businesses to commercialize ideas/technologies both internally and externally, leveraging external and internal tools as shown in figure (7b) (Elmansy, 2015). Projects can be launched from internal or external sources in an open innovation process and new technologies can be introduced at various stages. Projects can also be marketed in many ways, such as out-licensing or spin-off, besides traditional sales channels (Chesbrough, 2003).

Today, Open Innovation could be even more relevant in smart cities, where various private and public stakeholders work together to co-design and co-develop modern state-of-the-art products and services (Ojasalo \&Tähtinen, 2016 and Tali, 2018). Nearly all municipality decision-making officials have heard about innovation and emerging technologies but there are no concrete action plans for implementation. At the same time there is a growing understanding among municipality decisionmakers that the use of emerging technologies is unavoidable in the near future. Technology development is depending on the availability of relevant skills and human resources (Cankar \& Petkovšek, 2013).

Open innovation platforms provide an operating model compatible with public and private sector challenges for the reform of urban services and business growth activities (Raunio, Nordling, Ketola, P. Saarinen \& Heinikangas, 2016). The term "Innovation Platform" is described as an approach that systematically promotes innovation by external actors with the goal of creating solutions to their own problems and needs (Ojasalo, 2015). In this research, the platform owner refers to municipalities who owns problems and needs. The platform-based operation method can thus be viewed as a key tool for digital urban development which highlights participatory development, using which the innovation effect and the participatory dimension of development can be significantly increased (Raunio et al., 2016). The use of co-creation allows many more consumer-orientated services to be provided. The start-ups are actively involved in public service creation across platforms.

Such digitally-enabled crowdsourcing for innovation is made effective through two mechanisms. First is the ability to recruit and leverage external collaborators (Baldwin \& Von Hippel, 2011). Research has shown that distinctive ideas are manifest in the participation of more collaborators, not by relying on a small group of individuals with great range (Boudreau, 2012). Digital technologies provide channels of connectivity and platform scaffolding that enable spontaneous collaboration between those actors; i.e. problem owners (municipalities) and problem solvers (start-ups) as shown in figure (8). Second, the Open Innovation Network will serve as the gateway for both problem owners and problem solvers to plug into the ecosystem for partnerships. The open innovation network features various stakeholders from corporates, government agencies, donors, for-profit, non-profit and ecosystem enablers calling for tech and digital solutions collaboration across diverse domains. Eventually, there is a hope to scale this up to a regional platform. It is important for all parties involved to feel they receive a significant value in return for platform-based activities. By participating, platform users generate added value for each other. A successful platform creates a network effect that allows stakeholders to feel that they receive so much value for working with others that they return to the platform.

\section{Conclusions And Future Research}

Public sector innovators do not innovate in a vacuum, but in a structured organizational environment. Innovative municipal workers may not go very far if the organizational environment is not conducive to innovation. If the local municipalities' organization structure consists of people who understand and accept the importance of innovation and emerging technologies in modern government, then activities in this field are included in the plans of the municipality and will be supported. With regard to staff capacity, there are problems in municipalities because they do not have the capacity to develop emerging technologies. Gaza Strip municipalities need to provide start-ups and researchers with the appropriate conditions to use the resources, knowledge and ecosystems that the municipality possesses to create innovation that can help develop smart cities more competitively. 
The open innovation platform-based tool described in this research can be seen to function as digital and physical interfaces that enable the participation of different start-ups and researchers in developing emerging technologies. These interfaces are a significant part of the structure of the innovativeness of the municipalities. The aim is to provide an overview of this area of platform-based development, its fundamental elements and resources, so that we can tackle its challenges more effectively and comprehensively than before.

Financial technology (FinTech) start-ups got the lowest investment opportunities in Palestine during the past years although the high interest in the FinTech solutions field by different sectors including the municipal sector. Further research is required to provide a conceptual basis for enhancing FinTech applications in Palestine. It is recommended to review current regulations and assess how we can build an improved framework to attract and accommodate legal high-calibre FinTech entrepreneurs while providing good consumer and investor security to ensure financial stability.

This research also leads to some observations that might be of interest to future researchers for examining the application of e-Commerce in the public sector. The municipalities' representatives did not show any interest in the e-Commerce solutions, therefore it is important to shed some light on the opportunities to exploit e-Commerce in the public sector by gathering together the many lessons learned from the public sectors around the world as to reiterate the successful applications in the municipal sector.

\section{Abbreviations}

Al: Artificial Intelligence

IoT: Internet of Things

FinTech: Financial Technology

Ol: Open Innovation

G2G: Government to Government

G2C: Government to Customer

G2B: Government to Business

\section{Declarations}

\section{Availability of Data And Materials}

The datasets generated and/or analyzed during the current study are available from the corresponding author on reasonable request.

\section{Acknowledgements}

The author would like to acknowledge Ms Azza Zeyad AlSahhar for her great support, useful discussions and refining manuscript.

\section{Funding}

This work has been developed through collaboration made possible by Business and Technology Incubator (BTI) and 10X Project. 10X Project "Fostering Palestinian Youth' Entrepreneurship and Innovation via Enhancing Capacities of the Main Actors on the Palestinian Ecosystem to Promote Welfare and Competitiveness of the Palestinian Economy" which funded by 
the Swiss Agency for Development and Cooperation (SDC) under supervision of United Nations Development Programme (UNDP).

\section{Author information}

Affiliations

Business and Technology Incubator, Islamic University of Gaza, Palestine.

Ashraf Y. AlAstal

Contributions

This manuscript was authored solely by the corresponding author. The author read and approved the final manuscript.

Author's information

Ashraf Y. AlAstal holds a Master degree in Business Administration from the Islamic University of Gaza and a B.Sc. degree in Computer Engineering from Applied Science University as well as multiple professional certificates in the fields of Project Management, Microsoft Systems Engineer and Blockchain Technology. Ashraf is having an international recognition and senior memberships from multiple organizations and initiatives; and representing Palestine as a national expert of UN-based digital contest; World Summit Awards. Moreover, he has participated as a judge for many national and international digital initiatives. He has been awarded multiple prizes for his outstanding performance. His achievements include also academic and research papers and books. Currently, he is working as a Technical/Business Development Advisor and as a Visiting Lecturer in the national universities.

Corresponding author

Correspondence to Ashraf Y. AlAstal.

\section{Ethics declarations}

Competing interests

The author declares no competing interests.

\section{References}

AlAstal, A. (2018). Bridging The Gap: Assessing The Funding Landscape For Palestine's Start-ups. Entrepreneurship and Investment Conference, Islamic University of Gaza, Gaza, Palestine.

Baldwin, C., \& Von Hippel, E. (2011). Modeling a paradigm shift: From producer innovation to user and open collaborative innovation. Organization Science 22(6), 1399-1417.

Barnes, D., Buckland, B. \& Brancheau J. (1992). Methodological issues in emerging technologies research: Experiences and recommendations. Proceedings of the Twenty-Fifth Hawaii International Conference on System Sciences, 4, 325-336.

Basole, C. (2018). Visualizing Ecosystems of Hype. Proceedings of the $51^{\text {st }}$ Hawaii International Conference on System Sciences. DOI:10.24251/HICSS.2018.621

Boudreau, K. (2012). Let a thousand flowers bloom? An early look at large numbers of software app developers and patterns of innovation. Organization Science 23(5), 1409-1427. 
Burnett, C. \& Lemardeley, R. (2011). Measuring Innovation: Sustaining Competitive Advantage By Turning Ideas Into Value. BearingPoint Research.

https://www.bearingpoint.com/files/Innovation_High_Res.pdf

Cankar, S. \& Petkovšek, V. (2013). Private And Public Sector Innovation And The Importance Of Cross-Sector Collaboration. The Journal of Applied Business Research Volume 29, Nr. 6.

Cassell, C. \& Symon, G. (1994). Qualitative Methods in Organisational Research. Sage Publications, London, Sage. Cearley, D. (2020). The Top 10 Strategic Technology Trends for 2020. Complimentary full research, Gartner research. http://www.prospectivayestrategia.cl/pdf/top-tech-trends-2020-ebook.pdf

Chesbrough, H. (2003). The Era of Open Innovation. MIT Sloan Management Review.

https://sloanreview.mit.edu/article/the-era-of-open-innovation

CompTIA (2020). International Trends in Technology and Workforce. The Computing Technology Industry Association, CompTIA.

https://connect.comptia.org//content/research/international-trends-workforce-cybersecurity-emerging-tech

Deloitte-a (2020). Tech Trends 2020. Emerging Technology research, Deloitte Insights.

https://www2.deloitte.com/content/dam/Deloitte/za/Documents/technology/za_DI_Tech_Trends_2020_Africa(006).pdf

Deloitte-b (2020). Evolving Technology Trends: Is your bank ready for tomorrow?. Emerging Technology research, Deloitte Middle East.

https://www2.deloitte.com/content/dam/Deloitte/xe/Documents/technology/me_evolving-tech-trends.pdf

Dube, S. \& Danescu, D. (2011). Supplemental Guidance: Public Sector Definition. Reference Material, The Institute of Internal Auditors.

https://global.theiia.org/standards-guidance/Public\%20Documents/Public\%20Sector\%20Definition.pdf

Eggers, W. \& Bellman, J. (2015). The Journey To Government's Digital Transformation. A Deloitte Digital global survey, Deloitte University Press.

https://www2.deloitte.com/content/dam/insights/us/articles/digital-transformation-in-government/DUP_1081_Journey-togovt-digital-future_MASTER.pdf

Elmansy, R. (2015). Implementing Open Innovation to Drive Creativity inside Organizations. Research report, Designorate. https://www.designorate.com/wp-content/uploads/2015/03/Designorate_Report_Open_Innovation.pdf

Ferraris, A., Santoro, G. \& Claudia Pellicelli, A. (2020). Openness of public governments in smart cities: removing the barriers for innovation and entrepreneurship. International Entrepreneurship and Management Journal 16, 1259-1280.

Frost \& Sullivan (2020). ICT Market in the Middle East, Forecast to 2024. Global Information \& Communication Technologies Research Team. 
https://store.frost.com/ict-market-in-the-middle-east-forecast-to-2024.html

IoD (2018). Digital Government And The Productivity Puzzle: The Case For Partnership Between The Public And Private Sectors. Institute of Directors (IoD) Policy Report.

https://www.iod.com/Portals/0/PDFs/Campaigns\%20and\%20Reports/Digital\%20and\%20Technology/Digital-govt-

productivity-puzzle.pdf?ver=2017-12-21-114748-427

Jaffal, A. (2018). Assessment Of Innovative Approaches In Inclusive Service Delivery And Local Governance In The OPT. Palestine Economic Policy Research Institute (MAS).

Jayasena, N., Mallawaarachchi, H. \& Waidyasekara, K. (2019). A Critical Review On The Drivers And Barriers For Enabling Smart Cities. Proceedings of the International Conference on Industrial Engineering and Operations Management, Bangkok, Thailand.

Jullien, C. \& Lemardeley, R. (2018). Accelerating Open Innovation In The Public Sector. BearingPoint Research.

https://www.bearingpoint.com/files/LB_OpenInnovation_Insight.pdf?download=0\&itemld=494395

Kay, R. \& Goldspink, C. (2013). Public Versus Private Sector Innovation - A Case Of Apples And Oranges. The Australian Institute of Company Directors. Keeping Good Companies, 65(1), 17-23.

Kay, R. \& Goldspink, C. (2016). Public Sector Innovation: Why It's Different. The Australian Institute of Company Directors. https://aicd.companydirectors.com.au/ /media/cd2/resources/advocacy/governance-leadership-centre/pdf/05493-1-polglc-public-sector-innovation-research-paper-a4-may16_web.ashx

Karakas, C. (2020). Public Sector Innovation: Concepts, Trends And Best Practices. European Parliamentary Research Service. https://www.europarl.europa.eu/RegData/etudes/BRIE/2020/651954/EPRS_BRI(2020)651954_EN.pdf

Kusumasari, B., Pramusinto, A., Dwi Santoso, A. \& Audori Fathin, C. (2019). What Shapes Public Sector Innovation?. Public Policy Administration Research Journal, T. 18, Nr. 4, p. 430-446.

Lindskog, H. \& Wennberg, H. (2002). Learning From "Big Brother": Public Sector e-Commerce As A Role Model For Swedish Industry. Accessed through SemanticScholar research tool.

Magnitt (2019). 2019 Mena Venture Investment Summary. A start-up research firm that connects investors, mentors, and emerging companies in the Middle East.

Mazurkiewicz, A. (2018). Barriers Of Technological Innovation Development And Implementation Encountered By R\&D Organisations. Institute for Sustainable Technologies, National Research Institute, Radom, Poland.

MDLF (2009). Public Private Partnership In The Municipalities. The Municipal Development And Lending Fund, Palestine.

MDLF (2019). Annual Report 2019. The Municipal Development And Lending Fund, Palestine.

MOLG (2018). E-Municipality Strategic Framework 2019-2023. Ministry of Local Government, Palestine.

Morar, R. (2018). Overview Of The Digital And Innovation Ecosystem In Palestine. Palestine Economic Policy Research Institute (MAS).

Mulgan, G. (2014). Innovation In The Public Sector: How Can Public Organisations Better Create, Improve And Adapt?. Nesta, the UK's innovation foundation. 
https://media.nesta.org.uk/documents/innovation_in_the_public_sector-

_how_can_public_organisations_better_create_improve_and_adapt_0.pdf

Mulgan, G., and Albury, D. (2003). Innovation In The Public Sector. Cabinet Office Strategy Unit, United Kingdom Cabinet Office.

http://www.sba.oakland.edu/faculty/mathieson/mis524/resources/readings/innovation/innovation_in_the_public_sector.pdf Ojasalo, J. (2015). Open Innovation Platform in a Smart City: Empirical Results. The Journal of American Business Review Cambridge, 4(1), 195-202

Ojasalo, J. \& Tähtinen, L. (2016). Integrating Open Innovation Platforms in Public Sector Decision Making: Empirical Results from Smart City Research. Technology Innovation Management Review. Technology Innovation Management Review, 6(12): $38-48$.

Orton-Jones, C. (2018). Public Sector technology: Government Must Be Smarter Buying Tech. An Independent Publication By RACONTEUR, Number 537.

Paunov, C. (2012). Innovation For Development: A Discussion Of The Issues And An Overview Of Work Of The OECD Directorate For Science, Technology And Industry. Organisation for Economic Co-operation and Development.

https://www.oecd.org/innovation/inno/50586251.pdf

PITA (2018). EXPOTECH Final Technical Report. Palestine Technology Week, Palestinian Information Technology Association of Companies.

Potjanajaruwit, P. \& Girdwichai, L. (2019). Creative Innovation Of Startup Businesses In Thailand. Journal of International Studies, 12(3), 222-231.

Przeybilovicz, E., Alexandra Cunha, M. \& de Souza Meirelles, F. (2018). The Use Of Information And Communication Technology To Characterize Municipalities: Who They Are And What They Need To Develop E-Government And Smart City Initiatives. Rev. Adm. Pública vol.52 nr.4 Rio de Janeiro.

Rammal, I. \& Abuoun Hamad, S. (2008). Planning Capacities within the Palestinian Municipalities. 1st International Conference on Urban Planning in Palestine: Current Challenges \& Future Prospects, Al Najah University, Palestine.

Raunio, M., Nordling, N., Ketola, T., P. Saarinen, J. \& Heinikangas, A. (2016). Open Innovation Platforms: An Approach to City Development. (1. edition, version 1.5.), [Council of Tampere Region].

Sawatzky, A., Slemon, K. \& Grills, T-A. (2017). "Exploring Municipal Innovation For The 2017 Municipal Innovators Community Conference". Guelph, ON: Community Engaged Scholarship

Institute. https://atrium.lib.uoguelph.ca/xmlui/handle/10214/8902

Shahwan, U. \& Soudah, R. (2005). "Public-Private Partnership: A Strategy for Economic Development in Palestine". Bethlehem University Journal, vol. 24, 2005, pp. 9-30.

Sheppard, M., McCarron, M., Gelb, D., Mabbott, J. \& Fogarty, J. (2015). Why Are Big Businesses Looking To Start-Ups For Innovation?. Paper published by KPMG Group. https://assets.kpmg/content/dam/kpmg/pdf/2015/02/big-business-startups-innovation.pdf

Shearmur, R. \& Poirier, V. (2016). Exploring Municipal Innovation: Technological And Original Innovation In Municipalities. Institut national de la recherche scientifique Centre - Urbanisation Culture Société, Montreal. DOI:10.13140/RG.2.1.1882.9847 
Tali, G. (2018). Start-up and open innovation. Master thesis, New Jersey Institute of Technology.

Theses. 1579.

https://digitalcommons.njit.edu/theses/1579

UNECE, (2017). Innovation In The Public Sector. United Nations publication issued by the Economic Commission for Europe. https://unece.org/DAM/ceci/publications/Innovation_in_the_Public_Sector/Public_Sector_Innovation_for_web.pdf Waghmare, V., Patil, J. \& Khandekar, S. (2015). Application Of GIS In Planning Of Facilitate Infrastructure. International Journal of Advance Research in Computer Science and Management Studies, Volume 3, pg. 356-362.

\section{Figures}

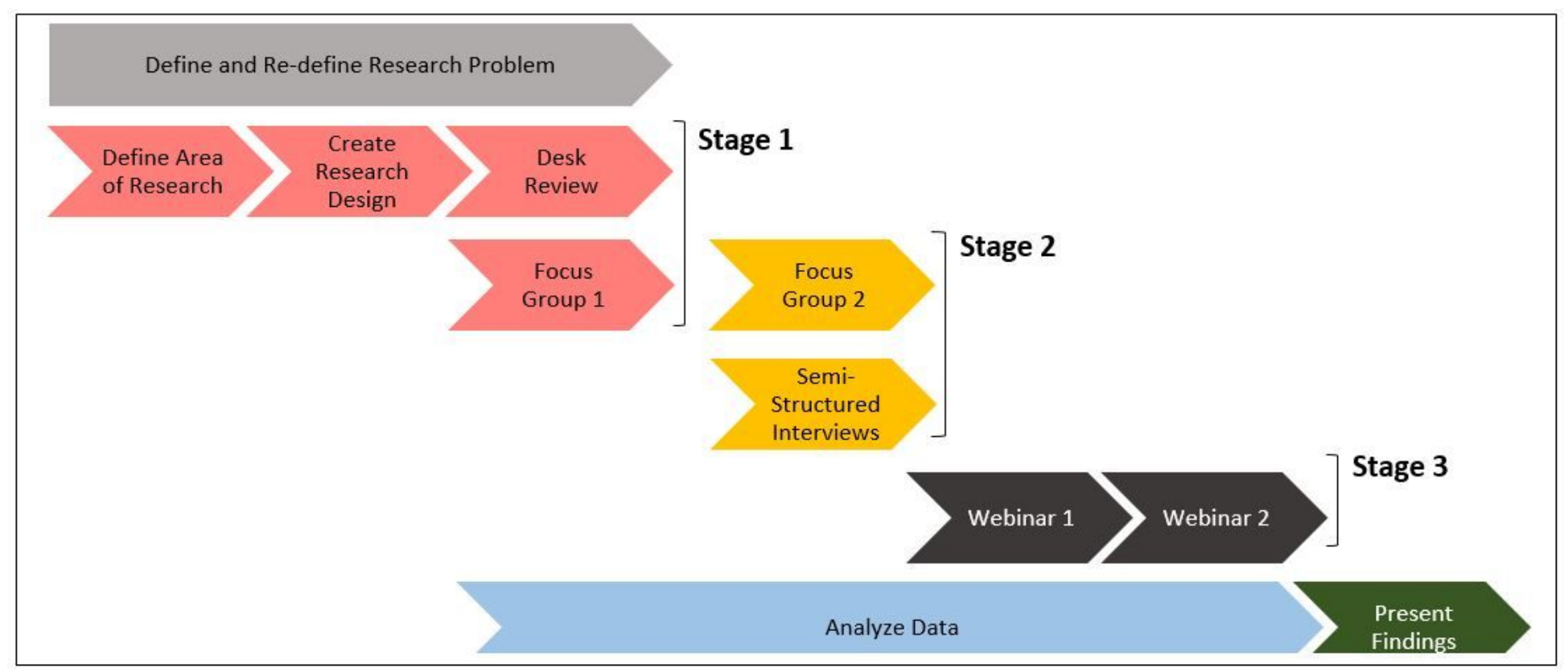

Figure 1

Research Process 


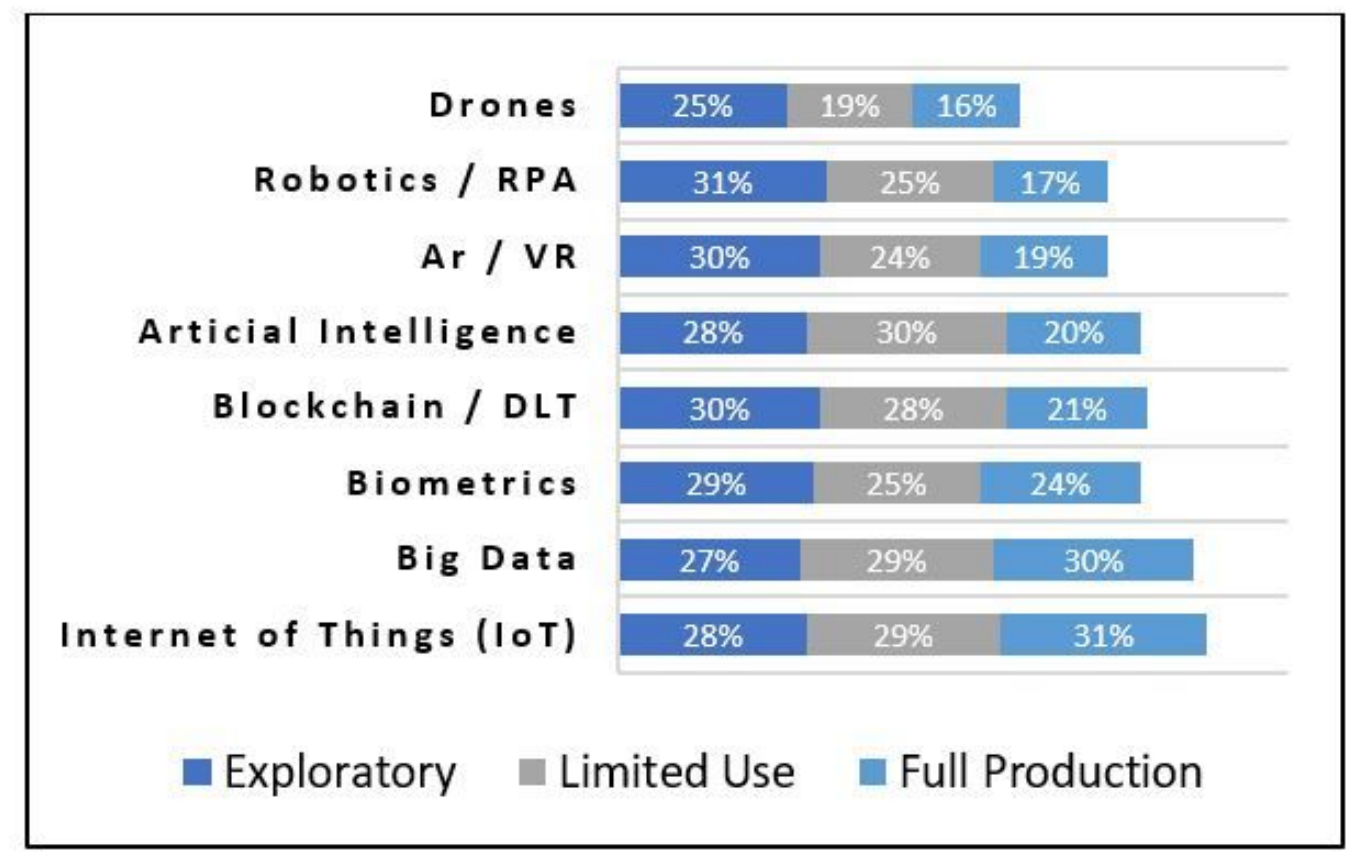

Figure 2

Emerging Technology Adoption Source: (CompTIA, 2020)

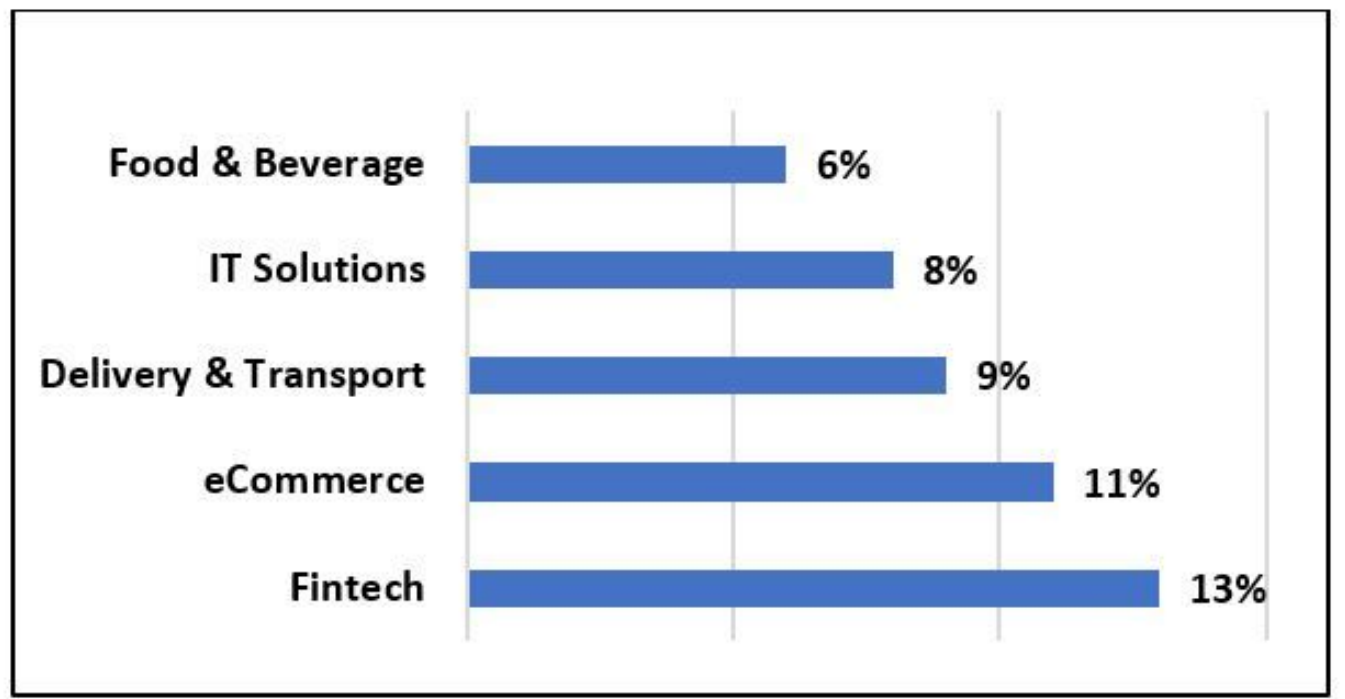

Figure 3

MENA's top 5 industries by number of deals in 2019 Source: Reproduced from (Magnitt, 2019) 


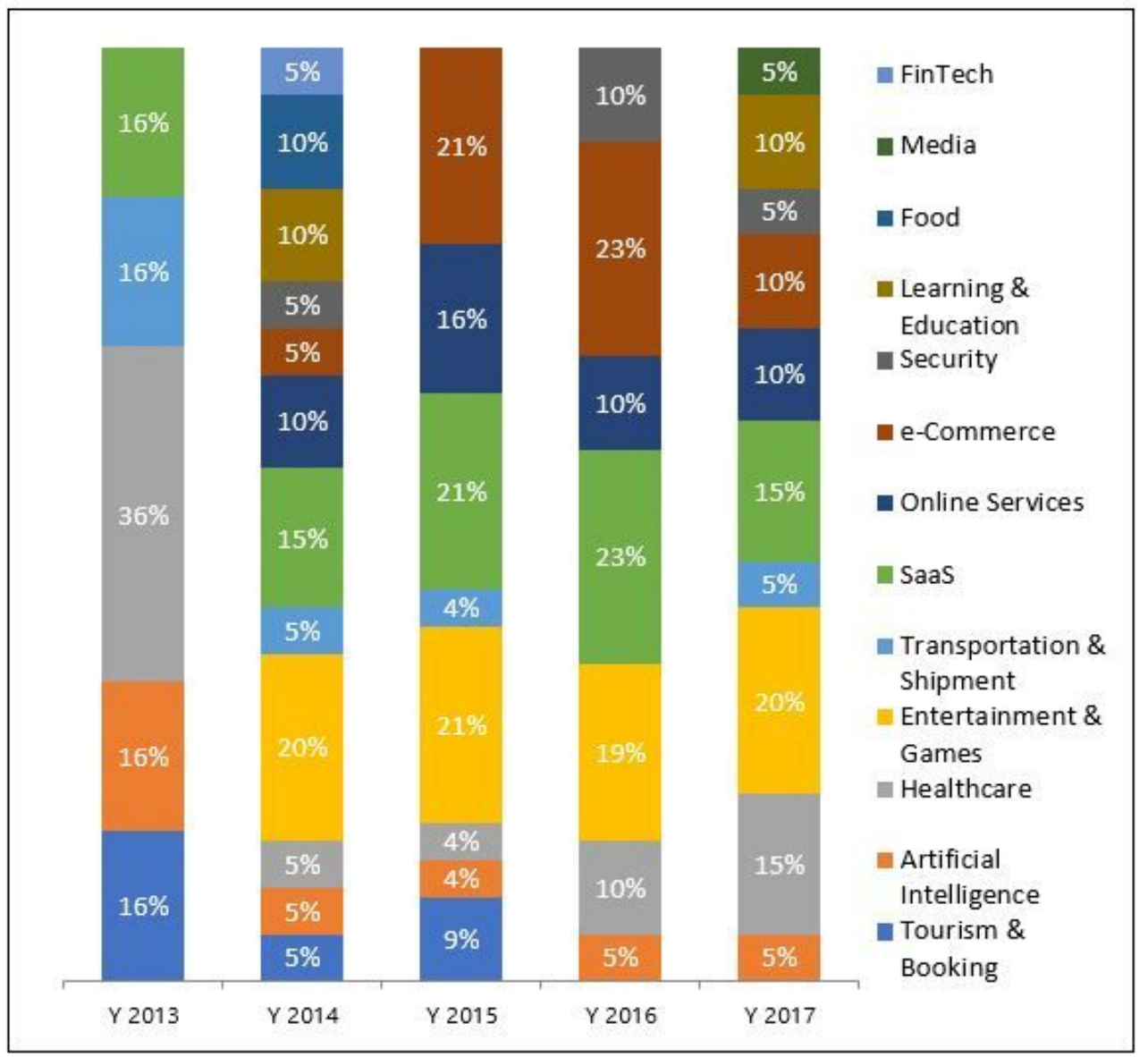

Figure 4

Percent number of investments by sector by year Source: (AlAstal, 2018).

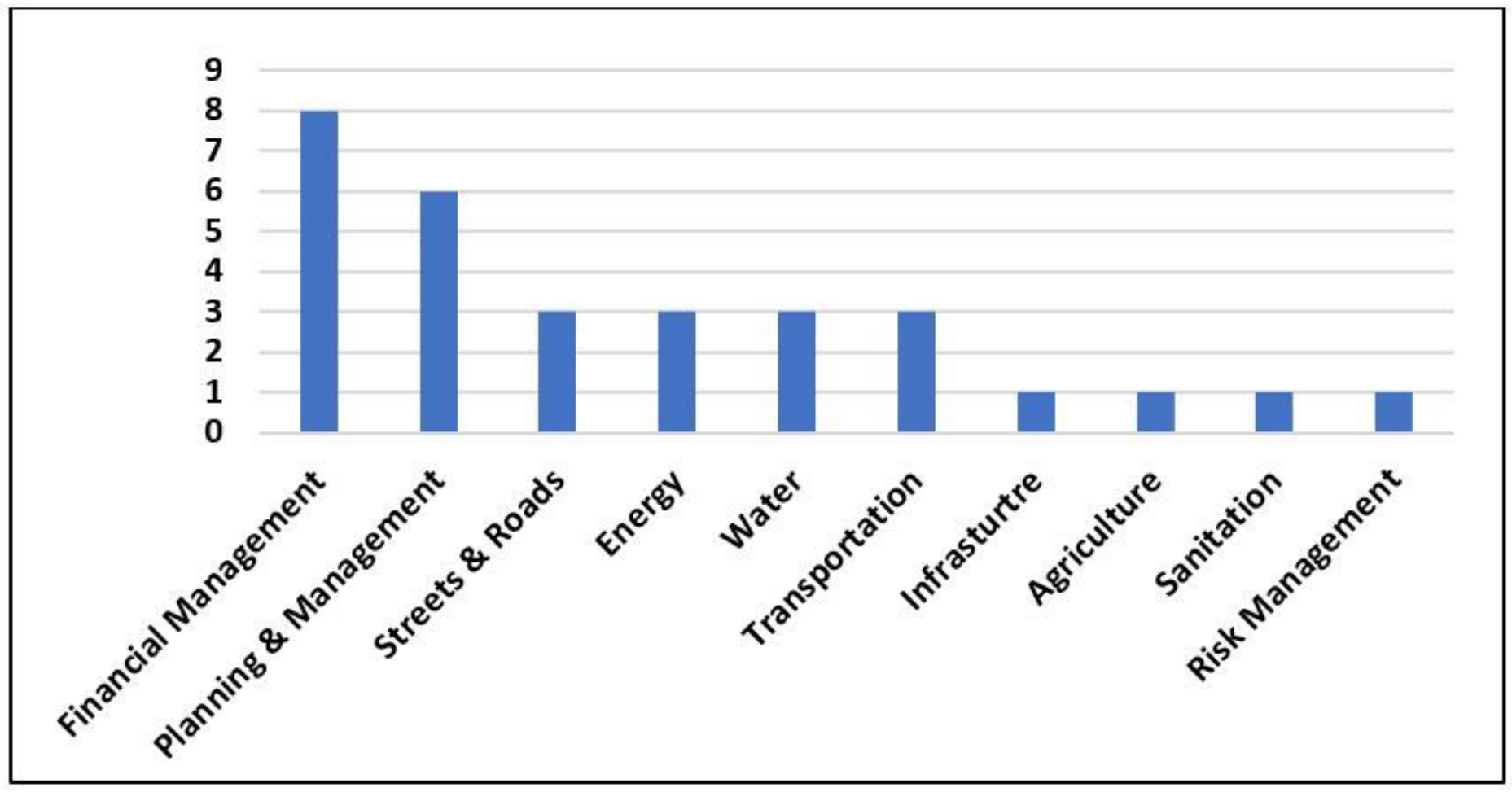

Figure 5 


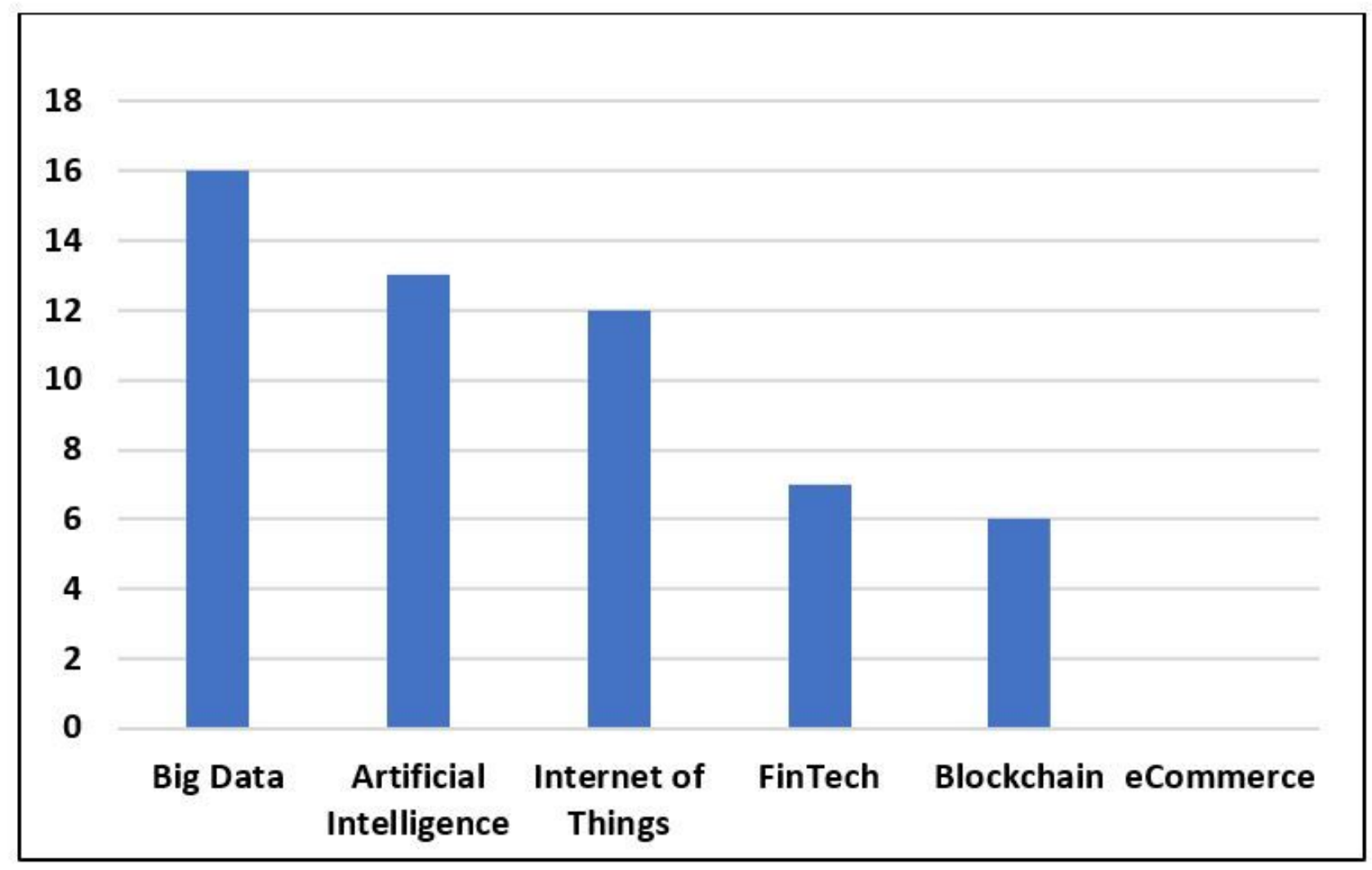

Figure 6

Classifying challenges according to its importance to developing an integrated solutions Source: (Articulated by the researcher, 2020) 

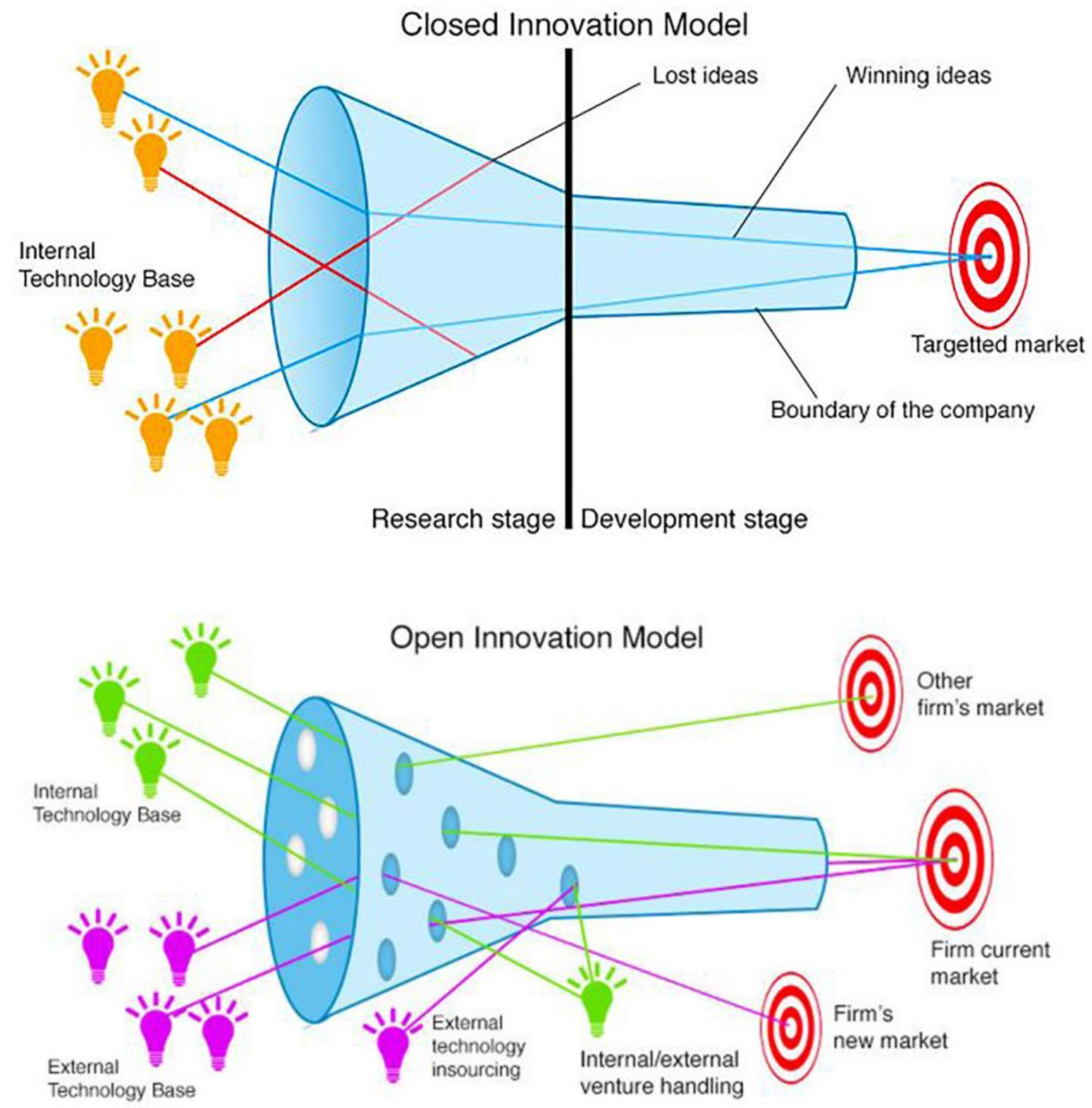

Figure 7

a) Ideas flow in the closed innovation model Source: (Elmansy, 2015) b) Internal and external ideas flow an open innovation model Source: (Elmansy, 2015) 


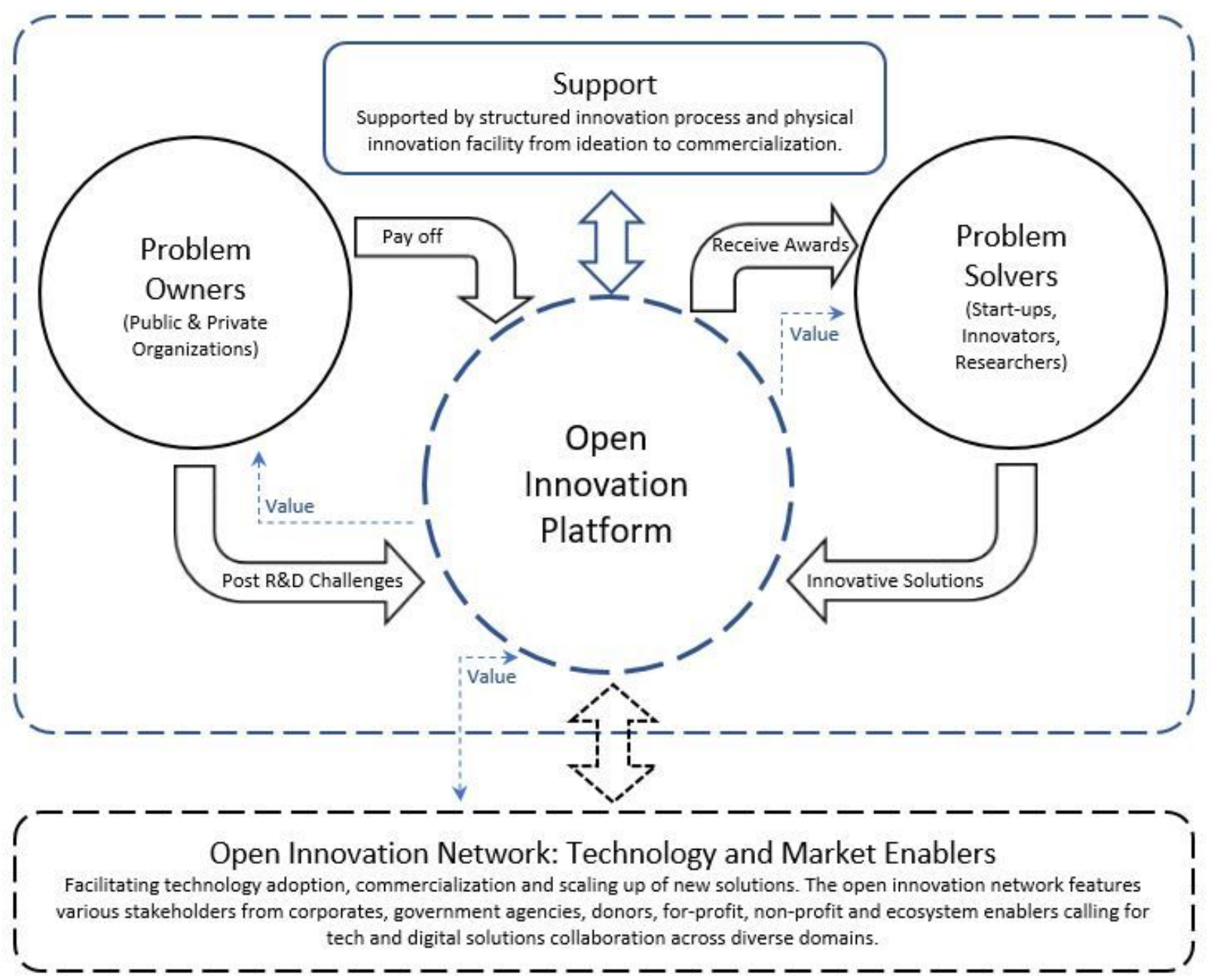

Figure 8

Suggested framework for open innovation platform supported by an open innovation network. Source: (Articulated by the researcher, 2020) 